\title{
The effect of modified citrus pectin-probiotic on faecal lactobacilli in Balb/c mice
}

\author{
Frederick ODUN-AYO ${ }^{1 *}$, John MELLEM² ${ }^{2}$ Lalini REDDY³
}

\begin{abstract}
Intestinal bacteria utilize the constituent of ingested food for their metabolic activities making the gut microbiota a target in the modification of functional foods. This study examines the effect of modified citrus pectin and encapsulated probiotic, Lactobacillus acidophilus ATCC 4356 on colon lactobacilli microbiota in healthy Balb/c mice. Mice were orally administered once daily with modified citrus pectin alginate probiotic, alginate calcium probiotic, modified citrus pectin and water for 28 days. Faecal lactobacilli count were determined using automated colony counter Doc-It ${ }^{\circledR}$ imaging station. The number of faecal lactobacilli in the modified citrus pectin alginate probiotic-treated mice significantly increased at day 7, 14 and 28 [7.99 \pm 0.22 , $8.32 \pm 0.08$ and $8.36 \pm 0.23\left(\log _{10} \mathrm{cfu} / \mathrm{g}\right)$ respectively]. A little or no increase in the faecal lactobacilli count was noted in the modified citrus pectin-treated mice. Modified citrus pectin alginate combined with live probiotic, Lactobacillus acidophilus ATCC 4356 supplements can be used as probiotic therapy to improve the intestinal lactobacilli microbiota in healthy host.
\end{abstract}

Keywords: modified citrus pectin; supplements; lactobacilli; microbeads.

Practical Application: Improving intestinal microbiota using modified citrus pectin alginate- probiotic.

\section{Introduction}

Microorganisms are unevenly distributed at different sites of the digestive tract; stomach $\left(<10^{3}\right)$, duodenum $\left(<10^{3}\right)$, small intestine $\left(10^{2}-10^{3}\right)$ and large intestine $\left(10^{10}-10^{12}\right)$ (Aureli et al., 2011). The human gut microbiota consists of hundreds of types of microorganism with an estimated value of over $10^{13}-10^{14}$ bacteria playing an important role in maintaining the health of the body. Some of these bacteria grow and colonize the intestinal region of the host becoming the intestinal microbiota, which stands as a line of defense against pathogenic organism. A relatively small number of bacteria are enumerated in the stomach and small intestine compared to the large intestine owing to antimicrobial effect of the gastric acid and peristalsis motility in a healthy subject. A slight disruption of the intestinal microbiota community or disorder in the interaction between the flora and the host can cause the host to be susceptible to infectious diseases (Sekirov et al., 2010). The balance in interaction existing between the gut microbiota and the host therefore must be maintained.

Constant supply of functional foods such as probiotics and prebiotics has demonstrated a beneficial effect to the gut when sufficient viable amounts are consumed by the host. Probiotic products consumed daily must contain a standard minimum of $10^{6}-10^{7} \mathrm{cfu} / \mathrm{g}$ products per day (Food and Agriculture Organisation, 2002; Krasaekoopt et al., 2003). Studies have indicated the effect of oral consumption of probiotic products on the faecal microbiota in human adults (Wang et al., 2014) and rats (Mountzouris et al., 2009). Probiotics are thought to exert beneficial effect on the host by enhancing digestion thus improving the host's nutrition; enhance gut barrier function through competition with pathogen for nutrition and adhesion receptor on the epithelial mucosa; stimulate gut epithelial cell proliferation (Mountzouris, 2007).

Modified citrus pectin (MCP), a natural polysaccharide used as supplements for cell proliferation, is treated enzymatically to break down the galactans into smaller fragments. In a clinical study carried out to determine the clinical benefit of oral MCP intake in tumour patient, common side effect observed includes flatulence and dyspepsia (Azémar et al., 2007). Morris (2009) suggested "[...] better understanding of the effects of MCP on the release of the pectin-derived galactans, the effects of transit, digestion and colonic fermentation and its circulation within the body would allow the optimization of MCP as an alternative therapy $[. .$.$] ". Modified pectin may have need of a$ particular food supplements to achieve maximum bioactivity (Maxwell et al., 2012). Therefore in this study, the effect of probiotic Lactobacillus acidophilus ATCC 4356 with/without MCP on the faecal lactobacilli microbiota population in healthy $\mathrm{Balb} / \mathrm{c}$ mice was examined.

\section{Materials and methods}

\subsection{Lactobacillus acidophilus ATCC 4356 growth conditions and harvesting}

Frozen stock culture of L. acidophilus ATCC 4356 (Microbiologics, St Cloud, MN) was rehydrated in De Mann, Rogosa and Sharpe (MRS) broth (Sigma Aldrich, St. Louis, M.O, USA) and incubated at $37^{\circ} \mathrm{C}$ for 48 hours under aerobic condition (Chávarri et al., 2010). The culture was transferred 
into fresh MRS broth and incubated under the same condition as before to obtain cell count between $9-10 \log _{10} \mathrm{cfu} / \mathrm{g}$. Cells were harvested by centrifugation at $3150 \times g$ for $5 \mathrm{~min}$ at $4{ }^{\circ} \mathrm{C}$ and serially diluted $\left(10^{1}-10^{10}\right)$ in sterile saline $(0.9 \% \mathrm{NaCl})$ solution. Afterwards, $100 \mu \mathrm{l}$ cell aliquots were plated onto MRS agar and incubated at $37^{\circ} \mathrm{C}$ for 48 hours under anaerobic condition using Anaerocult ${ }^{\circledR}$ jar. Number of cells harvested were counted using the automated colony counter Doc-It ${ }^{\circledR}$ imaging station (UVP, C.A, USA) and recorded in $\log _{10} \mathrm{cfu} / \mathrm{g}$. Fresh cell suspensions of $L$. acidophilus ATCC 4356 were prepared for each microencapsulation procedure and enumerated by pour plating in MRS agar. Plates were incubated under the same condition as before.

\subsection{Preparation of microencapsulated probiotic}

Modified citrus pectin (ecoNugenics Inc. CA, USA) is a natural product obtained from the peel and pith of Citrus $s p$. The pectin is enzymatically modified into smaller fragments having less than $10 \%$ degree of esterification. Sodium alginate (Sigma Aldrich, St. Louis, M.O., USA) is a natural polysaccharide product extracted from the cell wall of brown sea weed. Both MCP and sodium alginate were finally obtained in a dry powder form and used as received. Modified citrus pectin alginate (MCPA) and alginate calcium (AC) probiotic microencapsulation were produced aseptically and separately at room temperature using emulsification polymerization method (Homayouni et al., 2008). To produce the microencapsulated MCPA; MCP (8.5\%) and sodium alginate $(2 \%)$ were mixed in distilled water and agitated on rotary shaker for $10 \mathrm{~min}$. The microencapsulated AC were produced by adding sodium alginate (2\%) in distilled water and agitated for $10 \mathrm{~min}$. Cell suspension $(1 \mathrm{ml})$ of L. acidophilus ATCC 4356 containing $9.60 \log _{10}$ cfu/g was added to the polymer matrix emulsion in canola oil. The mixture was emulsified by adding lecithin $(0.1 \%)$ with a constant agitation at $1130 \times g$ for $40 \mathrm{~min}$. Calcium chloride $(0.1 \mathrm{M})$ solution was added to the polymer mixture to harden the beads and was agitated for $5 \mathrm{~min}$. Thereafter, the MCPA or AC probiotic microbeads were collected by centrifugation at $3150 \times g$ for $5 \mathrm{~min}$ at $4{ }^{\circ} \mathrm{C}$. Chitosan $(0.2 \mathrm{~g})$ (Sigma Aldrich, St. Louis, M.O., USA) was dissolved in $1 \%(\mathrm{v} / \mathrm{v})$ of acetic acid. Then MCPA or AC probiotic microbeads were dropped gently from a $10 \mathrm{ml}$ syringe into the gently agitated $100 \mathrm{ml}$ chitosan solution in a flask at $1130 \times g$ for $15 \mathrm{~min}$ on a magnetic stirrer for coating. The microbeads were allowed to settle down, later retrieved by centrifugation at $3150 \mathrm{x} g$ for $5 \mathrm{~min}$ at $4{ }^{\circ} \mathrm{C}$, repeatedly washed with saline solution to remove remnants and stored in sodium glycerol $(0.9 \% \mathrm{NaCl}, 5 \%$ glycerol $)$ solution at $4{ }^{\circ} \mathrm{C}$. The microencapsulated L. acidophilus ATCC 4356 (MCPA and AC) were broken down by gently shaking $1 \mathrm{~g}$ of the microbead in $9 \mathrm{ml}$ of sterile phosphate buffer solution (PBS) $\mathrm{pH}$ (7.4) for 10 min using orbital shaker (Sheu \& Marshall, 1993; Annan et al., 2008). Cell suspensions $(100 \mu \mathrm{l})$ in serial dilution $\left(10^{1}-10^{9}\right)$ carried out in triplicates were plated on MRS agar and incubated at $37^{\circ} \mathrm{C}$ for 48 hours under aerobic condition. Viable number of cell growth recorded in $\log _{10} \mathrm{cfu} / \mathrm{g}$ was enumerated using automated colony Doc-It ${ }^{\circledR}$ imaging station (UVP, C.A, USA). The polymer microbeads (MCPA and AC) released between 8-9 $\log _{10} \mathrm{cfu} / \mathrm{g}$ of viable L. acidophilus ATCC 4356.

\subsection{Animal model}

Post institutional ethics approval (084/14/Animal) was obtained prior to commencement of the animal trial and the experiment was carried out at the Biomedical Research Unit (BRU), University of KwaZulu-Natal (UKZN). The BRU approved standard protocols for animal treatment were followed. Seven-week-old male Balb/c mice weighing 20-25 g were weaned and kept in groups of 10 per cage. The mice were housed under a controlled condition of humidity $(50 \pm 10 \%)$ and temperature $\left(23 \pm 2{ }^{\circ} \mathrm{C}\right)$ on a 12 hours light/dark cycle for 7 days of pre-experimental adaption to their new environment with free access to normal standard chow (diet) and water. The beddings were cleaned out on daily basis and excess faeces were removed. During the experiment mice were carefully observed for any abnormal behaviour.

\subsection{Probiotic treatments and collection of faecal samples}

The total study population $(n=40)$ consisted of four groups of Balb/c mice ( $n=10)$ each. The microencapsulated MCPA- and AC probiotic, MCP solution $(3 \mathrm{~g} / \mathrm{ml}$ ) or water (control) were administered at a volume of $0.2 \mathrm{ml}$ by gavage (intragastric) using 15-16 gauge bulbed-ended needle cannula, once daily for 28 days as shown in Table 1 . Water and food were available to the animals ad libitum throughout the experiment. Faecal samples were taken for each group of mice at days 0 (before treatment), 7, 14 and 28 (during treatment). Faecal samples collected in sterile disposables tubes containing sterile saline solution kept in ice packs were transported to the laboratory and processed within 2 to 12 hours of collection. Samples were serially diluted in saline $(0.9 \% \mathrm{NaCl})$ from $10^{1}$ up to $10^{10}$ and inoculated onto MRS agar (selective medium to isolate lactobacilli) anaerobically for 48 hours at $37^{\circ} \mathrm{C}$. Colonies from the faecal samples plates between $30-300 \mathrm{cfu} / \mathrm{ml}$ were counted using the automated colony counter Doc- $\mathrm{It}^{\circledR}$ imaging station and recorded in $\log _{10} \mathrm{cfu} / \mathrm{g}$. Total number of viable lactobacilli were enumerated in triplicate. Plates were subcultured on MRS agar to obtain pure colonies. Shiny, entire, smooth/rough, circular and opaque colonies in anaerobic condition were noted.

Table 1. Category of treatments administered for the Balb/c mouse model.

\begin{tabular}{clc}
\hline Groups & \multicolumn{1}{c}{ Treatments } & Average faecal lactobacilli count $(\mathbf{l o g}$ cfu/g) at day 0 \\
\hline 1 & Modified citrus pectin alginate (MCPA) probiotic microbeads & $7.60 \pm 0.23$ \\
2 & Alginate calcium (AC) probiotic microbeads & $8.21 \pm 0.19$ \\
3 & Modified citrus pectin (MCP) & $8.08 \pm 0.05$ \\
4 & Water (control) & $8.02 \pm 0.19$ \\
\hline
\end{tabular}




\subsection{Statistical analysis}

Data was subjected to Tukey's test and ANOVA, as appropriate, for comparative analysis and to determine significant differences among the groups. Graphpad Prism software and SPSS version 24.0 for Windows (SSPS, Chicago, Illinois, USA) was used. Results were presented as means \pm standard deviation (SD), a $\mathrm{p}<0.05$ value was considered significant.

\section{Results and discussion}

The average number of viable faecal lactobacilli count $\left(\log _{10} \mathrm{cfu} / \mathrm{g}\right)$ from the MCPA probiotic-, AC probiotic-, MCP-treated and control mice is shown in Figure 1. At the initial stage (day 0) of probiotic treatment of the mice, slight variation of faecal lactobacilli count was detected in all the groups most particularly in the MCPA group that shows relatively low lactobacilli faecal count compared to other groups. At day 7 of probiotic treatment, the number of faecal lactobacilli in the MCPA probiotic-treated group was significantly increased $\left(7.99 \pm 0.22 \log _{10} \mathrm{cfu} / \mathrm{g}\right.$; $\mathrm{p}<0.05$ ). Conversely, reduced number of faecal lactobacilli was detected in the AC probiotic-, MCP-treated and control groups $\left[8.14 \pm 0.20,8.06 \pm 0.05,7.85 \pm 0.04\left(\log _{10} \mathrm{cfu} / \mathrm{g}\right)\right.$ respectively; $\mathrm{p}>0.05]$, though not significant. At day 14 of probiotic treatment, the viable faecal lactobacilli in the MCPA probiotic-treated mice increased progressively $\left(8.32 \pm 0.08 \log _{10} \mathrm{cfu} / \mathrm{g} ; \mathrm{p}<0.001\right)$. Also, there was slight increase of faecal lactobacilli count in the AC probiotic-treated $\left(8.34 \pm 0.05 \log _{10} \mathrm{cfu} / \mathrm{g}\right)$ and control $\left(8.12 \pm 0.01 \log _{10} \mathrm{cfu} / \mathrm{g}\right)$ groups while further reduction of faecal lactobacilli was noted in MCP-treated mice $\left(8.03 \pm 0.06 \log _{10} \mathrm{cfu} / \mathrm{g}\right.$; $\mathrm{p}>0.05)$. For the probiotic treatment at day $28 v s$ day 0 , a significant increase was noted in the number of faecal lactobacilli in the MCPA probiotic-treated group only $(8.36 \pm 0.23 \mathrm{vs}$ $\left.7.60 \pm 0.23 \log _{10} \mathrm{cfu} / \mathrm{g} ; \mathrm{p}<0.001\right)$. As regards AC probiotic- and MCP-treated groups $\left[8.22 \pm 0.02\right.$ and $8.08 \pm 0.14\left(\log _{10} \mathrm{cfu} / \mathrm{g}\right)$ respectively], there was no significant increase in the faecal

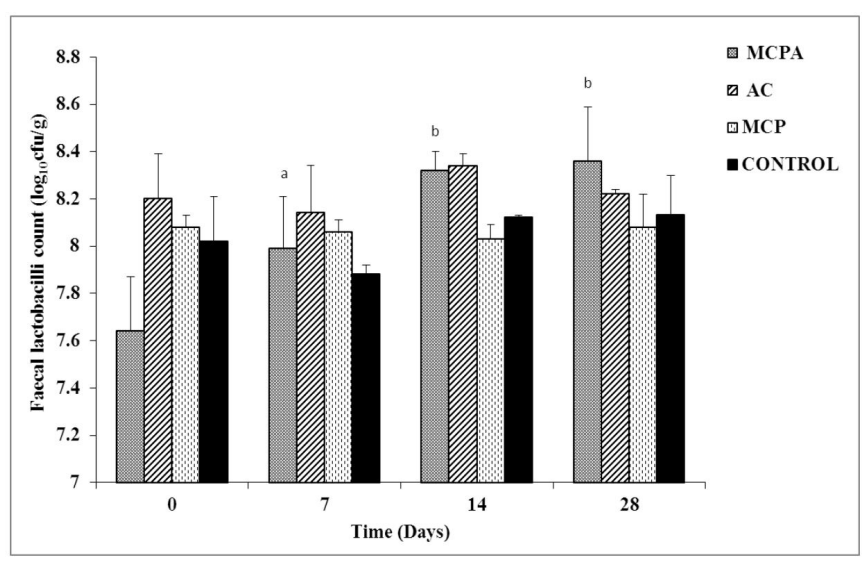

Figure 1. Average faecal lactobacilli count $\left(\log _{10} \mathrm{cfu} / \mathrm{g}\right)$ in mice administered with modified citrus pectin alginate Lactobacillus acidophilus ATCC 4356 probiotics (MCPA), alginate calcium Lactobacillus acidophilus ATCC 4356 probiotics (AC), modified citrus pectin solution (MCP) and water (control) for 28 consecutive days. Bar represent means for 10 mice per treatment \pm SD. Bars with different superscripts $(a, b)$ differ significantly $(\mathrm{p}<0.05, \mathrm{p}<0.001$ respectively) from day 0 . lactobacilli count $(\mathrm{p}>0.05)$. No variation was observed in the control group and no death of animal.

The highest number of viable faecal lactobacilli during the treatment period was detected in the MCPA probiotic-treated mice compared to the AC probiotic-, MCP-treated and control groups. Our findings corroborate Yen et al. (2011), as the study demonstrates greater increase of lactobacilli in faecal sample after consumption of probiotic.

In this present study following the oral consumption of MCPA and the probiotic, L. acidophilus ATCC 4356, consistent increase of the faecal lactobacilli population was noted. The effect of the different treatments (MCPA probiotic, AC probiotic and MCP) on the faecal lactobacilli count of the mice indicated that the faecal lactobacilli was probably influenced by the interaction of colon microbiota with the probiotic bacteria, L. acidophilus ATCC 4356 supplemented with MCP. Although, there was no significant difference in the number of faecal lactobacilli count between the MCP-treated mice and control ( $p>0.05)$, the reduced faecal lactobacilli presented by MCP-treated mice corroborates the observation made by Doyle (2007), Biagi et al. (2010) and Zhong et al. (2014) that pectin stimulates bacteria other than lactic acid bacteria. Conversely, some studies showed that citrus pectin encourages the proliferation of lactobacillus species which is dependent on the composition and prebiotic index of the pectic fraction-arabinan and galactan (Onumpai et al., 2011), degree of methylation and selective fermentation of pectin (Olano-Martin et al., 2002).

This study demonstrated significant increase of faecal lactobacilli in mice treated with MCPA probiotic compared to MCP-treated group. However, it is plausible to assume that the MCPA probiotic may have influenced the stimulation of colonic microbiota in the mice compared to the AC probiotic and MCP. This may also be due to indirect effects of other bacteria concentrations, level of short-chain fatty acid, colonic enzyme levels and reduction of DNA damage or DNA adducts formation (Pool-Zobel et al., 1996; De Preter et al., 2007). It has been generally recommended that probiotic concentration of $10^{6}-10^{9} \mathrm{cfu} / \mathrm{g}$ or $10^{8}-10^{10} \mathrm{cfu} /$ day is considerably sufficient to exert beneficial effect in a host (Shah, 2001). One of the key roles of the intestinal lactobacilli is to maintain the integrity of epithelia mucosa of the intestine via ability to catabolize complex polysaccharides into short chain fatty acids (SCFAs-butyrate, lactic acids, acetic acid and propionate) which are major energy source to the epithelium cells of the colon (Macfarlane \& Macfarlane, 2012; Serban, 2014). Pectin influences metabolism in the gut through colonic fermentation thus affects intestinal bacteria (Wicker et al., 2014). Thus it is plausible to presume that the disintegration of modified pectin citrus and alginate calcium by both L. acidophilus ATCC 4356 and endogenous microbiota might have induced SFCAs, gases and butyrate for their survival. These SCFAs reduce the effect of bile in the intestine by initiating bile salt hydrolase which deconjugates bile acid (Ooi \& Liong, 2010). Supplementation of lactobacillus with prebiotics could reduce bile acid conversion whose reabsorption into the gut may become co-carcinogenic (Zampa et al., 2004).

The colonization of $L$. acidophilus ATCC 4356 in the gut would be competitive with indigenous bacteria population which 
utilizes the polysaccharides (modified citrus pectin and alginate) as substrates for their growth and survival. The composition of endogenous lactobacilli differs in individual which significantly impact the establishment of exogenous lactobacilli. This suggests that the colonization of probiotic is associated with stable indigenous lactobacilli population (Yen et al., 2011). Limitation to this study is in vivo sampling of the colon tissue as some lactobacilli may colonized discrete areas in the mouse intestinal tract or remain adherent to the mucosal surfaces and therefore remain non-detectable from the faeces using microbiological agar. However, further studies would clarify the detection of the probiotic and its effect on the increase of the feacal lactobacilli as to whether endogenous and/or exogenous lactobacilli within the gastrointestinal tract.

\section{Conclusions}

This study demonstrated that the daily intake of MCPA probiotic L. acidophilus ATCC 4356 increased the faecal lactobacilli of the mice after 28 days of probiotic consumption. Modified citrus pectin alginate probiotic microbead presents to be a novel and effective oral delivery of bacterial cells and also an adjunct (combined with health beneficial bacteria) to supplementary dietary. The addition of $L$. acidophilus ATCC 4356 with MCP and alginate increases the number of feacal lactobacilli in the mice. Therefore, the co-administration of live probiotic, L. acidophilus ATCC 4356 with MCP supplement helps to maintain and /or improve the integrity and population of the intestinal microbiota.

The use of MCPA can be a potential probiotic therapy which improves the fragmentation of MCP bioactivity in the host thus provides protection against intestinal diseases. Further molecular characterization would reveal the mechanism and uptake of the fragment molecules responsible for MCPA bioactivity.

\section{Acknowledgements}

The authors are thankful to the Research Department, Durban University of Technology, South Africa for the financial support.

\section{References}

Annan, N. T., Borza, A. D., \& Hansen, L. T. (2008). Encapsulation in alginate-coated gelatin microspheres improves survival of the probiotic Bifidobacterium adolescentis 15703 T during exposure to simulated gastro-intestinal conditions. Food Research International, 41(2), 184-193. http://dx.doi.org/10.1016/j.foodres.2007.11.001.

Aureli, P., Capurso, L., Castellazzi, A. M., Clerici, M., Giovannini, M., Morelli, L., Poli, A., Pregliasco, F., Salvini, F., \& Zuccotti, G. V. (2011). Probiotics and health: an evidence-based review. Pharmacological Research, 63(5), 366-376. PMid:21349334. http://dx.doi.org/10.1016/j. phrs.2011.02.006.

Azémar, M., Hildenbrand, B., Haering, B., Heim, M. E., \& Unger, C. (2007). Clinical benefit in patients with advanced solid tumours treated with modified citrus pectin: a prospective pilot study. Clinical Medicine, Oncology, 1, 73-80.

Biagi, G., Cipollini, I., Grandi, M., \& Zaghini, G. (2010). Influence of some potential prebiotics and fibre-rich foodstuffs on composition and activity of canine intestinal microbiota. Animal Feed Science and Technology, 159(1-2), 50-58. http://dx.doi.org/10.1016/j. anifeedsci.2010.04.012.

Chávarri, M., Marañón, I., Ares, R., Ibáñez, F. C., Marzo, F., \& Villarán, M. D. C. (2010). Microencapsulation of a probiotic and prebiotic in alginate-chitosan capsules improves survival in simulated gastrointestinal conditions. International Journal of Food Microbiology, 142(1-2), 185-189. PMid:20659775. http://dx.doi.org/10.1016/j. ijfoodmicro.2010.06.022.

De Preter, V., Raemen, H., Cloetens, L., Houben, E., Rutgeerts, P., \& Verbeke, K. (2007). Effect of dietary intervention with different preand probiotics on intestinal bacterial enzyme activities. European Journal of Clinical Nutrition, 62(2), 225-231. PMid:17327863. http:// dx.doi.org/10.1038/sj.ejcn.1602706.

Doyle, V. C. (2007). Nutrition and colorectal cancer risk: a literature review. Gastroenterology Nursing, 30(3), 178-182, quiz 182-183. PMid:17568255. http://dx.doi.org/10.1097/01.SGA.0000278165.05435.c0.

Food and Agriculture Organisation. (2002). World Health Organisation (W.H.O.) working group report on drafting guidelines for the evaluation of probiotics in food. Rome: FAO.

Homayouni, A., Azizi, A., Ehsani, M. R., Yarmand, M. S., \& Razavi, S. H. (2008). Effect of microencapsulation and resistant starch on the probiotic survival and sensory properties of synbiotic ice cream. Food Chemistry, 111(1), 50-55. http://dx.doi.org/10.1016/j. foodchem.2008.03.036.

Krasaekoopt, W., Bhandari, B., \& Deeth, H. (2003). Evaluation of encapsulation techniques of probiotics for yoghurt. International Dairy Journal, 13(1), 3-13. http://dx.doi.org/10.1016/S09586946(02)00155-3.

Macfarlane, G. T., \& Macfarlane, S. (2012). Bacteria, colonic fermentation and gastrointestinal health. Journal of AOAC International, 95(1), 50-60. PMid:22468341.http://dx.doi.org/10.5740/jaoacint.SGE_Macfarlane.

Maxwell, E. G., Belshaw, N. J., Waldron, K. W., \& Morris, V. J. (2012). Pectin - an emerging bioactive food polysaccharide. Trends in Food Science \& Technology, 24(2), 64-73. http://dx.doi.org/10.1016/j. tifs.2011.11.002.

Morris, V. J. (2009). Pectin galactans, galectins and health. Bioactive roles for pectin. Agro Food Industry Hi-Tech, 20, 37-40.

Mountzouris, K. C. (2007). Nutritional strategies targeting the beneficial modulation of the intestinal microbiota with relevance to food safety. In A. McElhatton \& R. J. Marshall (Eds.), Food safety: a practical and case study approach (Vol. 16; pp. 128-147). Amsterdam: Springer.

Mountzouris, K. C., Kotzampassi, K., Tsirtsikos, P., Kapoutzis, K., \& Fegeros, K. (2009). Effects of Lactobacillus acidophilus on gut microbiota metabolic biomarkers in fed and fasted rats. Clinical Nutrition (Edinburgh, Lothian), 28(3), 318-324. PMid:19223094. http://dx.doi.org/10.1016/j.clnu.2009.01.009.

Olano-Martin, E., Gibson, G. R., \& Rastell, R. A. (2002). Comparison of the in vitro bifidogenic properties of pectins and pectic-oligosaccharides. Journal of Applied Microbiology, 93(3), 505-511. PMid:12174051. http://dx.doi.org/10.1046/j.1365-2672.2002.01719.x.

Onumpai, C., Kolida, S., Bonnin, E., \& Rastall, R. A. (2011). Microbial utilization and selectivity of pectin fractions with various structures. Applied and Environmental Microbiology, 77(16), 5747-5754. PMid:21724897. http://dx.doi.org/10.1128/AEM.00179-11.

Ooi, L.-G., \& Liong, M.-T. (2010). Cholesterol-lowering effects of probiotics and prebiotics: a review of in vivo and in vitro findings. International Journal of Molecular Sciences, 11(6), 2499-2522. PMid:20640165. http://dx.doi.org/10.3390/ijms11062499.

Pool-Zobel, B. L., Neudecker, C., Domizlaff, I., Ji, S., Schillinger, U., Rumney, C., Moretti, M., Vilarini, I., Scassellati-Sforzolini, R., \& 
Rowland, I. (1996). Lactobacillus- and bifidobacterium-mediated antigenotoxicity in the colon of rats. Nutrition and Cancer, 26(3), 365380. PMid:8910918. http://dx.doi.org/10.1080/01635589609514492.

Sekirov, I., Russell, S. L., Antunes, L. C. M., \& Finlay, B. B. (2010). Gut microbiota in health and disease. Physiological Reviews, 90(3), 859904. PMid:20664075. http://dx.doi.org/10.1152/physrev.00045.2009.

Serban, D. E. (2014). Gastrointestinal cancers: Influence of gut microbiota, probiotics and prebiotics. Cancer Letters, 345(2), 258270. PMid:23981580. http://dx.doi.org/10.1016/j.canlet.2013.08.013.

Shah, N. P. (2001). Functional foods from probiotics and prebiotics. Food Technology, 22, 46-53.

Sheu, T. Y., \& Marshall, R. T. (1993). Microentrapment of Lactobacilli in calcium alginate gels. Journal of Food Science, 58(3), 557-561. http://dx.doi.org/10.1111/j.1365-2621.1993.tb04323.x.

Wang, L., Zhang, J., Guo, Z., Kwok, L., Ma, C., Zhang, W., Lv, Q., Huang, W., \& Zhang, H. (2014). Effect of oral consumption of probiotic Lactobacillus planatarum P-8 on fecal microbiota, SIgA, SCFAs, and TBAs of adults of different ages. Nutrition (Burbank, Los Angeles County, Calif.), 30(7-8), 776-783. PMid:24984992. http://dx.doi. org/10.1016/j.nut.2013.11.018.
Wicker, L., Kim, Y., Kim, M.-J., Thirkield, B., Lin, Z., \& Jung, J. (2014). Pectin as a bioactive polysaccharide: extracting tailored function from less. Food Hydrocolloids, 42, 251-259. http://dx.doi.org/10.1016/j. foodhyd.2014.01.002.

Yen, C.-H., Tseng, Y.-H., Yi-Wen, K., Meng-Chih, L., \& Hsiao-Ling, C. (2011). Long-term supplementation of isomalto-oligosaccharides improved colonic microbiota profile, bowel function, and blood cholesterol levels in constipated elderly people: a placebo-controlled, diet-controlled trial. Nutrition (Burbank, Los Angeles County, Calif.), 27(4), 445-450. PMid:20624673. http://dx.doi.org/10.1016/j. nut.2010.05.012.

Zampa, A., Silvi, S., Fabiani, R., Morozzi, G., Orpianesi, C., \& Cresci, A. (2004). Effects of different digestible carbohydrates on bile acid metabolism and SCFA production by human gut micro-flora grown in an in vitro semi-continuous culture. Anaerobe, 10(1), 19-26. PMid:16701496. http://dx.doi.org/10.1016/j.anaerobe.2003.12.002.

Zhong, L., Zhang, X., \& Covasa, M. (2014). Emerging roles of lactic acid bacteria in protection against colorectal cancer. World Journal of Gastroenterology, 20(24), 7878-7886. PMid:24976724. http:// dx.doi.org/10.3748/wjg.v20.i24.7878. 